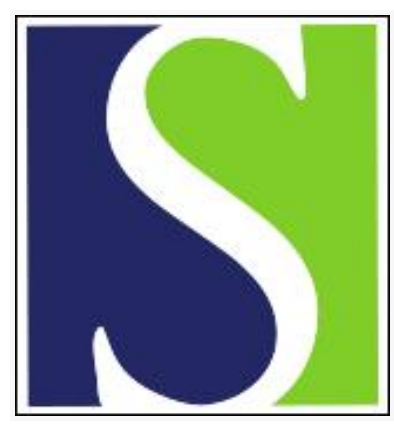

Scand J Work Environ Health 1981;7(3):185-189

https://doi.org/10.5271/sjweh.3110

Issue date: Sep 1981

Occurrence of cancer in a small cohort of asbestos-exposed workers

by Hilt B, Rosenberg J, Langård S

Affiliation: Department of Occupational Medicine, Telemark Sentralsjukehus, N-3900 Porsgrunn, Norway.

Key terms: asbestos; asbestos-exposed worker; cancer; cancer incidence; cohort; cohort study; exposure; radiographic change; worker

This article in PubMed: www.ncbi.nlm.nih.gov/pubmed/20120583

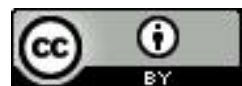




\title{
Occurrence of cancer in a small cohort of asbestos-exposed workers
}

\author{
by Bjørn Hilt, MD,' Jan Rosenberg, $M D,{ }^{2}$ Sverre Langård, $M D^{1}$
}

\begin{abstract}
HILT B, ROSENBERG J, LANGARD S. Occurrence of cancer in a small cohort of asbestos-exposed workers. Scand $j$ work environ health 7 (1981) 185-189. During the construction period of a saltpeter plant from 1928 through 1929, 21 young men of equal age were heavily exposed to asbestos dust for 1 a. During an observation period from 1 January 1943 to 30 June 1980 three cases of lung cancer and two cases of mesothelioma were observed in the cohort. The number of lung cancers to be expected was 0.21 . Radiographic changes associated with asbestos exposure were present in 17 of the 18 available chest radiographs.
\end{abstract}

Key terms: asbestos, cancer incidence, cohort study, radiographic changes.

During work on a cohort study regarding adverse effects of exposure to asbestos dust in a saltpeter plant located in southern Norway, a subcohort attracted attention. It was a group of 21 young men of similar age who, during the construction period of the plant from 1928 to 1929 , worked in the so-called fiber hut where they were heavily exposed to asbestos dust. Considering the classical meaning of the world cohort, this group would have nearly met the criteria for an ideal cohort had it not been so small in number.

The exposure took place 1 a after Cooke had introduced the term asbestosis for asbestos-related pneumoconiosis (6). It is conceivable that this knowledge had not reached Norway in 1928. Nevertheless, one of the men who worked there told us about a Swedish migrant worker who once watched the work in the fiber hut from the doorway and made the following comment: "It is diabolical that so many

1 Department of Occupational Medicine, Telemark Sentralsjukehus, Porsgrunn, Norway.

2 Health Department, Norsk Hydro as, Porsgrunn Fabrikker, Porsgrunn, Norway.

Reprint requests to: Dr B Hilt, Department of Occupational Medicine, Telemark Sentralsjukehus, N-3900 Porsgrunn, Norway. young men are going to die from fiber consumption." What did he know?

The present study is aimed at following the health experiences of the 21 workers who were employed in the fiber hut to determine what adverse health effects 1 a oî exposure at a young age to high concentrations of asbestos dust might have.

\section{Material and methods}

In the construction of the plant the acidresistant properties of asbestos were utilized in that asbestos was used to fill the grooves between the blocks in the huge granite towers (fig 1) where nitric acid was to be synthesized and stored. Young workers from the districts around the plant were employed in preparing this jointing material from asbestos and waterglass. The preparation took place in a room of about $40 \mathrm{~m}^{2}$, called the fiber hut. The work there caused so much dust that the employees could barely see across the room, which had no ventilation system or outlet. No equipment for personal protection was available.

It has been stated by the firm that delivered the asbestos to the plant that the type of asbestos generally delivered for this purpose was crocidolite. 


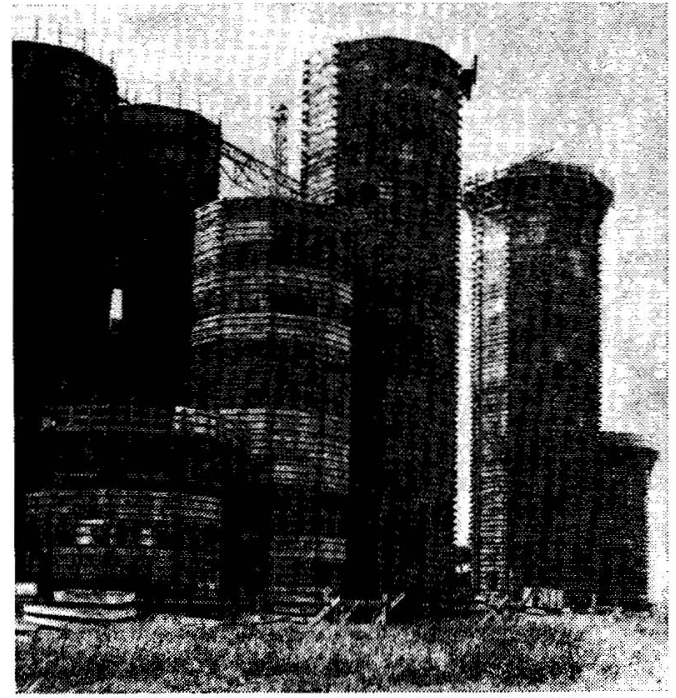

Fig 1. The nitric acid towers, about $30 \mathrm{~m}$ high, as they were built up from granite blocks. (photo: Norsk Hydro, Porsgrun.) Fabrikker, photographic archive).

The cohort consisted of all the men employed in this particular work during the construction period. All the participants were born between August 1910 and May 1914. The earliest personnel register of the plant was destroyed during the Second World War, and therefore a more unconventional method was used to identify the cohort. Three of the workers were still employed at the plant, and they assisted in tracing the names of the other workers from the fiber hut. By questioning these three workers and the four other men who were still living, we were able to identify the 14 deceased members of the cohort. It is believed that all the men who worked in the hut were traced. One of the men had committed suicide in 1936 at 25 a of age, and consequently he was excluded from the cohort.

The average length of exposure was about 1 a. Occupational exposure to asbestos at later dates could be excluded for all but two of the cohort members. No data on dust measurements at the workplace were available. One of the workers who had asbestosis died from right heart failure in 1971. Fiber counts from his lung tissue were carried out by the Institute of Occupational Health in Oslo; they showed a minimum of 28 million fibers per gram of tissue. In addition to the de- scription provided by the workers, this single result is reason for assuming that the dust concentration during the year of exposure had been very high.

Health information about the 13 deceased members of the cohort was gained primarily from their records at the local hospital and from their records at the health department of the plant. Some of the information was also traced through census rolls and from other hospitals. From these sources and from the relatives of the workers it was also possible to get information about their smoking habits. Those who had smoked during the last $10 \mathrm{a}$ of their lives were considered to be smokers.

Histologies were reviewed for all cancer cases which left any doubt about the histological type, and these revised tumor histologies were used in the present study. As a verification for the cancer cases, all members of the cohort were also linked with the figures of the Cancer Registry of Norway.

Considering the long clinical latency of asbestos-induced malignancies $(10,21)$, the observation period was defined as $1 \mathrm{Jan}$ uary 1943 through June 1980.

The age-specific incidence rates for all types of cancer for each calender year from 1955 through 1976 were available from the Cancer Registry of Norway $(3,4$, 5). By using a method earlier described by Pedersen et al (18) and by Langård \& Norseth (12), we calculated the expected figures for cancer in a hypothetical cohort consisting of the same number of men with an age distribution identical to that of the study population. The incidence rates for the years before 1955 were calculated as the mean for the years 19551957 , and similarly the incidence rates after 1976 as the mean value for the years 1974-1976. The expected rate for lung cancer (ICD code 162-163) was calculated during the observation period, until cancer was diagnosed, or until the year of death from some other reason.

The Cancer Registry has presented the yearly incidence rate of lung cancer per 100,000 for the whole country for the periods $1969-1971$ and $1972-1976$ as 31.5 and 36.3 , respectively, and 26.7 and 37.6 , respectively, for the county of Telemark where the plant is located $(4,5)$. Thus, 
using the incidence rates for the whole country as a basis for the calculation of the expected values will not result in any decisive errors.

A medical examination with attention to previous chest diseases, respiratory symptoms, chest auscultation, and lung function was carried out on the living members of the cohort. In the present paper the cancer incidence and the findings in the $35 \times 35$ chest radiographs are presented.

\section{Results}

There had been seven deaths from cancer. One patient suffering from malignant melanoma of the skin was still alive on 30 June 1980. In table 1 the distribution of the different forms of cancer is presented.

As can be seen from table 2, the observed/expected ratio for lung cancer (ICD 162-163) including the pleural mesothelioma, is 18.7 .

In table 3 the different forms of asbestos-related radiographic changes of the lungs observed among the cohort members are presented. For two of the deceased members it was impossible to trace any radiographs; therefore the number of subjects is 18 . Among these 18 men, 17 were found to have radiographic changes associated with asbestos exposure.

One of the two men with subsequent exposure to asbestos dust had occasionally been exposed during his work as a plumber in the same plant in the 1940s. He had pleural calcifications and died of lung cancer in 1973 . The other had worked with asbestos in the same plant during his entire work life. The radiographs showed parenchymal fibrosis and pleural calcifications in this worker, who suffered a sudden death at home in 1976.

A calculation of mortality rates for this small cohort has not been carried out, but it is clear that the members of the cohort have a reduced life expectancy in comparison with the male Norwegian population as a whole.

The mean latency periods for lung cancer found in this cohort was 46 a, and for mesothelioma it was 22 and 48 a.
Table 4 shows that all the fatal cancers observed in the cohort have, up till now, occurred among those considered smokers. Thus, the smoking members of the cohort have a cancer mortality of $43.8 \%$ before reaching the age of 65 a, compared with no cancer deaths among the nonsmokers. Among those considered smokers there were two who had stopped smoking during the last $10 \mathrm{a}$, and among the nonsmokers there were two exsmokers.

There was no difference in the prevalence of asbestos-related radiographic changes between the smokers and nonsmokers.

Table 1. Distribution of the different forms of cancer in the cohort $(N=20)$.

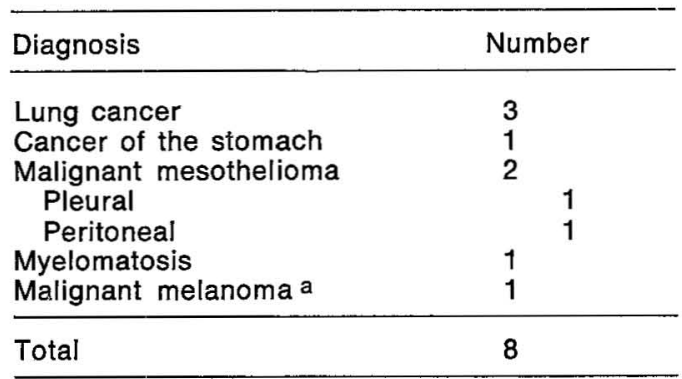

a Still alive by 1 July 80 .

Table 2. Occurrence of lung cancer.

\begin{tabular}{lccc}
\hline & $\begin{array}{c}\text { Observed } \\
\text { (O) }\end{array}$ & $\begin{array}{c}\text { Expected } \\
\text { (E) }\end{array}$ & O/E \\
\cline { 2 - 4 } $\begin{array}{l}\text { Lung cancer } \\
\text { (ICD 162-163) }\end{array}$ & $4^{\mathrm{a}}$ & 0.21 & $18.7^{\mathrm{b}}$ \\
\hline
\end{tabular}

a Including one case of pleural mesothelioma.

b $95 \%$ confidence interval $9.3-37.8$.

Table 3. Incidence of asbestos-related roentgenographic findings $(\mathrm{N}=18)$.

\begin{tabular}{lc}
\hline Finding & Incidence \\
\hline Parenchymal only & 4 \\
Parenchymal and pleural & 10 \\
Pleural only & 3 \\
\hline Total & $17 \quad(94.4 \%)$ \\
\hline
\end{tabular}


Table 4. Cancer mortality in the cohort in relation to smoking habits.

\begin{tabular}{lcccr}
\hline & $\begin{array}{c}\text { Pulmonary } \\
\text { cancer }\end{array}$ & $\begin{array}{c}\text { Malignant } \\
\text { mesothelioma }\end{array}$ & $\begin{array}{c}\text { Cancer at } \\
\text { other sites }\end{array}$ & Total \\
\cline { 2 - 5 } Smokers $(\mathrm{N}=16)$ & 33 & 2 & 2 & 7 \\
Nonsmokers $(\mathrm{N}=4)$ & $(18.7 \%)$ & $(12.5 \%)$ & $(12.5 \%)$ & $(43.8 \%)$ \\
\hline
\end{tabular}

\section{Discussion}

The observed/expected ratio for lung cancer found in this small cohort is similar to the ratio presented by Doll in 1955 (7), and to the figures found by Elmes \& Simpson in their studies of insulation workers in Belfast (8). These observed/expected figures are high in relation to the results found in other cohort studies on asbestos workers (21). Newhouse \& Berry found an observed/expected ratio of 2.4 for cancers of the lung and pleura for male factory workers who had been heavily exposed to asbestos for less than 2 a (17).

The finding of two mesotheliomas among the 13 deceased members of the cohort agrees well with the high mortality from mesothelioma presented in comparable cohort studies published during the last few years $(13,14,17)$.

In this study the latency periods were long. Up until 35 a after the first exposure no cancer death had occurred in the cohort, apart from the one pleural mesothelioma.

The great increase in cancer risk among smoking asbestos workers is now well known (20). It should be noted that all cancers in the respiratory organs found in this study were observed in smokers.

The one case of cancer of the stomach present in this cohort also represents an increase in relation to the expected number, but it cannot be discussed in relation to an observed/expected ratio.

When compared with other studies $(1,2$, $9,16,19,21)$ the percentage of radiographic changes associated with the asbestos exposure of the present cohort was high. It is therefore striking that, so far, just one of the cohort members has died as a result of parenchymal asbestosis.

The chest radiographic changes present among this study population were often slight and might easily be overlooked, but, as it has recently been shown by Weymann (22) and Hillerdal \& Lindgren (11), even the slightest of such radiographic signs has morphological substrates.

A relationship between smoking habits and the prevalence of asbestos-related radiographic changes has been suggested $(2,15,19)$, but for the present small material it was not possible to demonstrate any such relation.

It is remarkable that this small cohort of workers, exposed to asbestos dust 50 a ago for just 1 a, reveals such a high prevalence of asbestos-related radiographic changes and also has, compared to larger cohorts of workers from workplaces more usually associated with asbestos exposure, a high incidence of respiratory cancers. Whether this phenomenon is due to the assumed extremely high exposure, the long observation period, or to the young age of the workers at the time of exposure is difficult to judge. Nevertheless this small cohort has probably provided a better opportunity for an accurate characterization of the intensity and duration of the exposure for each individual member of the cohort.

\section{Acknowledgments}

We wish to express our gratitude for good cooperation to the staff of the health department in Norsk Hydro as, Porsgrunn Fabrikker, especially to Ms I Fritzon. We also thank Ms PA Flor for her linguistic help and Ms U Danielsen for typing the manuscript.

\section{References}

1. Becklake MR, Lindell FDK, Manfreda J, McDonald J. Radiological changes after withdrawal from asbestos exposure. $\mathrm{Br} \mathrm{j}$ ind med 36 (1979) 23-28. 
2. Berry G, Gilson JC, Holmes S, Lewinsohn HC, Roach SA. Asbestosis: A study of dose-response relationships in an asbestos textile factory. $\mathrm{Br} \mathrm{j}$ ind med 36 (1979) 98-112.

3. Cancer Registry of Norway. Trends in cancer incidence in Norway 1955-67. Universitetsforlaget, Oslo 1972.

4. Cancer Registry of Norway. The incidence of cancer in Norway $1969-71$. The Norwegian Cancer Society, Oslo 1973.

5. Cancer Registry of Norway. Incidence of cancer in Norway 1972-1976. The Norwegian Cancer Society, Oslo 1978.

6. Cooke WE. Pulmonary asbestosis. $\mathrm{Br}$ med j 2 (1927) 1024-1025.

7. Doll R. Mortality from lung cancer in asbestos workers. $\mathrm{Br} \mathbf{j}$ ind med 12 (1955) 81-86.

8. Elmes PC, Simpson MJC. Insulation workers in Belfast: A further study of mortality due to asbestos exposure (1940-75). $\mathrm{Br} \mathrm{j}$ ind med 34 (1977) 174-180.

9. Felton JS, Sargent EN, Gordonson JS. Radiographic changes following asbestos exposure: Experience with 7,500 workers. $\mathrm{J}$ occup med 22 (1980) 15-20.

10. Frank AL. Clinical observations following asbestos exposure. Environ health perspect 34 (1980) 27-30.

11. Hillerdal G, Lindgren A. Pleural plaques: Correlation of autopsy findings to radiographic findings and occupational history. Eur $\mathrm{j}$ respir dis 61 (1980) $315-319$.

12. Langård $S$, Norseth $T$. A cohort study of bronchial carcinomas in workers producing

Received for publication: 14 January 1981 chromate pigments. $\mathrm{Br} \mathrm{j}$ ind med 32 (1975) $62-65$.

13. Lemen RA, Dement JM, Wagoner JK. Epidemiology of asbestos-related diseases. Environ health perspect 34 (1980) $1-11$.

14. McDonald AD, McDonald JC. Mesothelioma after crocidolite exposure during gas mask manufacture. Environ res 17 (1978) $340-346$.

15. McMillan GHG, Pethybridge RJ, Sheers G. Effect of smoking on attack rates of pulmonary and pleural lesions related to exposure to asbestos dust. $\mathrm{Br} \mathrm{j}$ ind med 37 (1980) 268-272.

16. Michaels L, Chissick SS. Asbestos: Properties, applications and hazards. John Wiley \& Sons, Chichester 1979.

17. Newhouse ML, Berry G. Patterns of mortality in asbestos factory workers in London. Ann ny acad sci 330 (1979) 53-60.

18. Pedersen E, Høgetveit AC, Andersen A. Cancer in respiratory organs among workers at a nickel refinery in Norway. Int $j$ cancer 12 (1973) $32-41$.

19. Rossiter CE, Harries PG. UK naval dockyards asbestos study: Survey of sample population aged $50-59$ years. $\mathrm{Br} \mathrm{j}$ ind med 36 (1979) 281-291.

20. Selikoff IH, Hammond EC, Churg J. Asbestos exposure, smoking and neoplasia. $\mathrm{J}$ am med assoc 204 (1968) 106-112

21. Selikoff IJ, Lee DHK. Asbestos and disease. Academic Press, New York, NY 1978.

22. Weymann F. Untersuchungen zur Asbestsituation unter Werftangehörigen. Dissertation. Wilhelm Pieck Universität, Rostock 1979 . 